\title{
Allelic imbalance at 11q23-q24 chromosome associated with estrogen and radiation-induced breast cancer progression
}

\author{
D. ROY ${ }^{1}$, G.M. CALAF ${ }^{1,2}$, M.P.HANDE ${ }^{3}$ and T.K. HEI ${ }^{1}$ \\ ${ }^{1}$ Center for Radiological Research, College of Physicians and Surgeons, Columbia University, New York, NY, USA; \\ ${ }^{2}$ Department of Biology and Health, Faculty of Science, and Center for the Man in the Desert, University of Tarapaca, \\ Arica, Chile; ${ }^{3}$ Department of Physiology, Faculty of Medicine, National University of Singapore, Singapore
}

Received July 28, 2005; Accepted September 20, 2005

\begin{abstract}
Multiple genetic alterations are common in cancers including those of the breast. The mechanisms leading to these alterations such as point mutations, gene amplifications, deletions and replication error are often associated with frequent and consistent loss of heterozygosity ( $\mathrm{LOH}$ ) or microsatellite instability (MSI). Several cytological and molecular studies have shown high frequency loss of genetic information on the long arm of chromosome 11 (i.e., 11q) in various primary breast cancers. In the present study allelic alterations in a refined position on the long arm of chromosome 11 were studied to identify the spectrum of induced damage at different stages of malignant transformation of MCF-10F cell lines after exposure to high-LET radiation using $\alpha$-particles and exposure to estradiol by using PCR-single strand conformation polymorphism (SSCP) and fluorescence in situ hybridization (FISH) analysis. Microsatellite markers were selected from chromosome 11 (11q23-q24 loci) and it was found that frequency of allelic imbalance occurs at different stages of tumor progression with a range of $15-45 \%$ depending on the marker studied. These results strongly suggested the presence of several tumor suppressor genes in this critical region of chromosome 11 (11q23-q24). It also represents the first indication of allele loss at these loci in human breast epithelial cells induced by radiation and estrogen treatment suggesting a potential interventional target in breast carcinogenesis.
\end{abstract}

Correspondence to: Dr Debasish Roy, Present address: Biology Department, Brookhaven National Laboratory, \#463, 50 Bell Avenue, Upton, NY 11973, USA

E-mail: droy@bnl.gov

Abbreviations: DMEM, Dulbecco's modified Eagle's medium; $\mathrm{LOH}$, loss of heterozygosity; MSI, microsatellite instability; OD, optical density; $\mathrm{mFISH}$, multicolor fluorescence in situ hybridization; PCR-SSCP, polymerase chain reaction-single strand conformation polymorphism

Key words: allelic imbalance, estrogen, breast cancer

\section{Introduction}

Multiple genetic alterations are common in various cancers including those of the breast. Human cancers are thought to accumulate multiple genetic abnormalities as they progress from carcinoma in situ to metastatic phase (1). This process is often associated with frequent and consistent loss of heterozygosity (LOH) or microsatellite instability (MSI), which often seems to unmask recessive mutations in tumor suppressor loci (2). The involvement of tumor suppressor genes in neoplastic progression may be inferred by studies, which detect allelic losses in tumor DNA $(3,4)$. Defining specific chromosomal regions that harbor biologically important suppressor genes may, therefore, have broad practical implications in the diagnosis and management of these tumors $(5,6)$.

The development of breast cancer is the most common malignancy in women and the second leading cause of female cancer death, surpassed only by lung cancer $(7,8)$. In breast cancer, most genetic changes are not inherited but rather are somatically acquired in breast epithelial cells (9). There is evidence that multiple mechanisms including point mutations, gene amplifications, deletions and replication errors account for the genomic instability and mutation associated with neoplastic transformation. Acquisition of such genomic instability may represent an early step in carcinogenesis (10). Accordingly a large portions of genetic alterations are associated with the multi-step carcinogenesis of breast cancer. It is unclear whether allelic imbalance is the cause or the result of carcinogenesis but it is probably the most common genetic factor associated with cancer.

There is evidence that a significant number of aberrations (i.e., allelic alterations) on chromosomal regions $1 \mathrm{p}, 1 \mathrm{q}, 3 \mathrm{p}$, $6 \mathrm{q}, 7 \mathrm{q}, 11 \mathrm{p}, 13 \mathrm{q}, 16 \mathrm{q}, 17 \mathrm{p}, 17 \mathrm{q}$ and $18 \mathrm{q}$ are found in breast cancers $(11,12)$. Ionizing radiation is effective in producing these chromosomal aberrations, which are characterized either by MSI/LOH or by multicolor fluorescence in situ hybridization $(\mathrm{mFISH})$ analysis $(13,14)$. Epidemiological data also indicates that women exposed to ionizing radiation (e.g., radiation therapy during diagnosis and treatment, A-bomb etc.) have an increased risk of breast cancer (15). The action of ionizing radiation as a DNA-damaging agent, and consequently as a mutagen, is widely considered to be the basis for its action as a carcinogen (16). Allelic alterations (MSI/LOH) are 
believed to pinpoint the different locations of the recessive cancer genes to assess cancer risks.

Recently, several cytological and molecular studies have shown high frequency of loss of genetic information on the long arm of chromosome 11, particularly 11q23 in various primary breast cancers (17-19). Chromosome transfer experiments have also implicated chromosome 11q in breast cancer (20). These results strongly suggest the presence of at least one tumor suppressor gene in this critical region of 11 q23 $(17,19)$. Refinement of the minimal regions of $\mathrm{LOH}$ at $11 \mathrm{q} 23$ has helped to identify at least two independent regions of deletion in breast carcinomas: the $\mathrm{LOH}$ region 1 , defined between loci D11S2000 and D11S897, with an estimated size of $8 \mathrm{Mb}$, and the $\mathrm{LOH}$ region 2, between loci D11S1345 and D11S1316 of about $1 \mathrm{Mb}$ (20). Similarly, refined regions of deletion have also been identified in case of lung, ovarian and colorectal carcinomas (21-23).

At present, substantial information is available about chemically-induced cellular transformation and genetic alterations of breast tissues $(24,25)$, but little is known about such alterations induced by ionizing radiation. Complex chromosomal aberrations, defined as involving three or more breaks in two or more chromosomes is known to be induced after exposure to high-LET radiation, mainly of $\alpha$-particles (26-29). To have a better understanding of the cellular and molecular changes associated with these types of effects on a breast epithelial cell line, a recently developed, radiationinduced transformation model based on a spontaneously immortalized human breast epithelial (MCF-10F) cell line was utilized for this study (30). In our previous observations (31-33), the incidence of allelic imbalance at different chromosomal levels were reported. These imbalances involve overexpression of c-Ha-ras oncogene and altered expression of various other oncoproteins (34). Differential expression of a series of other oncogenes/tumor suppressor genes were also observed at different stages of neoplastic progression when $\mathrm{MCF}-10 \mathrm{~F}$ cell lines were induced by radiation and exposed to $17 ß$ estradiol.

To date, the full cytogenetic complexity of these aberrations has not been revealed because standard fluorescence in situ hybridization (FISH) techniques are limited in the number of chromosomes that can be 'painted'. The development of multiplex-FISH (mFISH) (13), however, has allowed the discrimination of all of the human chromosomes by using combinational labeling of individual chromosomes with spectrally distinct fluorophores. With the exception of interchanges between homologues, it allows all of the chromosomes participating in each aberration, within any cell, to be observed, and the relationship between different aberrant chromosomes to be determined (27). In the present study, we have utilized this model to determine the incidence of allelic imbalance in a refined position on the long arm of chromosome 11 . This study will also ascertain the possible translocation of this chromosome during neoplastic progression of the MCF-10F cell line. Since the transformed MCF-10F cell line underwent a series of phenotypic stages before becoming tumorigenic in nude mice (30), this information will help to understand the cellular and molecular targets involved during progression of radiation-induced breast carcinogenesis.

\section{Materials and methods}

Cell lines. The recently established radiation-induced, and estrogen-treated breast carcinogenesis model based on the MCF-10F cell line was used in these studies (30). The spontaneously immortalized human breast epithelial cell line, MCF-10F, was derived from the mortal human breast epithelial cell line, MCF-10M, and has a near diploid karyotype and is of luminal epithelial origin (35). These cells retain all the characteristics of normal epithelium in vitro, including anchorage-dependence, non-invasiveness and non-tumorigenicity in the nude mice $(35,36)$. Cell lines were cultured on Dulbecco's modified Eagle's media (DMEM) as described previously $(30,31,37)$. From this model, the following cell lines were used as controls: MCF-10F cell line; MCF-10F cell line treated with 173 -estradiol $(\mathrm{E})\left(10^{-8} \mathrm{M}\right)$ (Sigma Chemical Co., St. Louis, MO), named MCF-10F + E, and MCF-7, as a positive control $(30,38)$. The experimental cell lines were as follow: the MCF-10F cell line irradiated with a single dose of 60 cGy of $\alpha$-particle, named 60 cGy (passage 45-50) which was anchorage-dependent and non-tumorigenic in nude mice (30). This cell line was also grown in presence of estrogen after irradiation, and named $60 \mathrm{cGy}+\mathrm{E}$ (passage 48). Another MCF-10F cell line was treated with double doses of $60 \mathrm{cGy}$ of $\alpha$-particle, and named $60 \mathrm{cGy} / 60 \mathrm{cGy}$ (passage 44-48 as an early passage and passage $90-95$ as a late passage). It was anchorage-independent but non-tumorigenic in nude mice (30). This cell line was also grown in presence of estrogen after double doses of irradiation, and named $60 \mathrm{cGy} / 60 \mathrm{cGy}+$ E (passage 41). A final group of MCF-10F cell line was subjected to a double dose of $60 \mathrm{cGy}$ of $\alpha$-particle and treated with $\mathrm{E}$ before each radiation exposure; this line was named $60 c G y+E / 60 c G y+E$ (passage 45) and was both anchorageindependent and produced tumors in three out of six nude mice injected (30). Tumor 2 (passage 30) (34), one of the three primary tumor cell lines derived from the previous tumorigenic cell line was also used for this study. All the developed cell lines were mycoplasma tested from time to time to prevent any type of contamination.

DNA isolation. All cell cultures were treated with $1 \mathrm{ml}$ of lysis buffer $(100 \mathrm{mM} \mathrm{NaCl}, 20 \mathrm{mM}$ Tris- $\mathrm{HCl} \mathrm{pH} 8.0,25 \mathrm{mM}$ EDTA pH 8.0, 0.5\% sodium dodecyl sulfate) with $200 \mu \mathrm{g} / \mathrm{ml}$ of proteinase $\mathrm{K}$ and RNase $(100 \mu \mathrm{g} / \mathrm{ml})$, and incubated overnight at $37^{\circ} \mathrm{C}$ with constant gentle agitation (39). Then they were purified following two extractions with a phenol: chloroform (1:1) mixture and the aqueous layer was adjusted to $0.75 \mathrm{M}$ ammonium acetate and DNA was spooled from two volumes of $100 \%$ ethanol, dried, dissolved in TE buffer (10 mM Tris- $\mathrm{HCl} \mathrm{pH}$ 8.0, $1 \mathrm{mM}$ EDTA $\mathrm{pH}$ 8.0) and purified following the established procedure as described previously (40).

Microsatellite polymorphic marker selection. Eight polymorphic dinucleotide $(\mathrm{CA})_{\mathrm{n}}$ repeat microsatellite markers (Table I) (Research Genetics, Huntsville, AL) from chromosome 11q23-q24 (Fig. 1) were selected. They were selected on the basis of their maximum heterozygosity (more than 0.70 ) and their location near mapped, known, tumor suppressor genes, oncogenes, or other cancer related genes and in regions 
Table I. Characteristics of selected $(\mathrm{CA})_{\mathrm{n}}$ repeat markers on chromosome 11q23-q24.

\begin{tabular}{llccc}
\hline Chromosomal locus & Map position $^{\mathrm{a}}$ & Maximum heterozygosity & Type of sequence & Size range (base pairs) \\
\hline D11S29 & $11 \mathrm{q} 23.3$ & 0.792 & Dinucleotide & $143-163$ \\
D11S1340 & $11 \mathrm{q} 23.3$ & 0.670 & Dinucleotide & $188-200$ \\
CD3D & $11 \mathrm{q} 23.3$ & 0.764 & Dinucleotide & $85-99$ \\
NCAM & $11 \mathrm{q} 23$ & 0.780 & Dinucleotide & $94-138$ \\
D11S925 & $11 \mathrm{q} 23.3-q 24$ & 0.852 & Dinucleotide & $173-199$ \\
D11S1316 & $11 \mathrm{q} 23.3-q 24$ & 0.510 & Dinucleotide & $200-208$ \\
D11S1328 & 11q23.3-q24 & 0.744 & Dinucleotide & $151-165$ \\
D11S1345 & $11 \mathrm{q} 23.3-q 24$ & 0.711 & Dinucleotide & $232-240$ \\
\hline
\end{tabular}

aPrecise location of the markers on respective chromosomal arms.

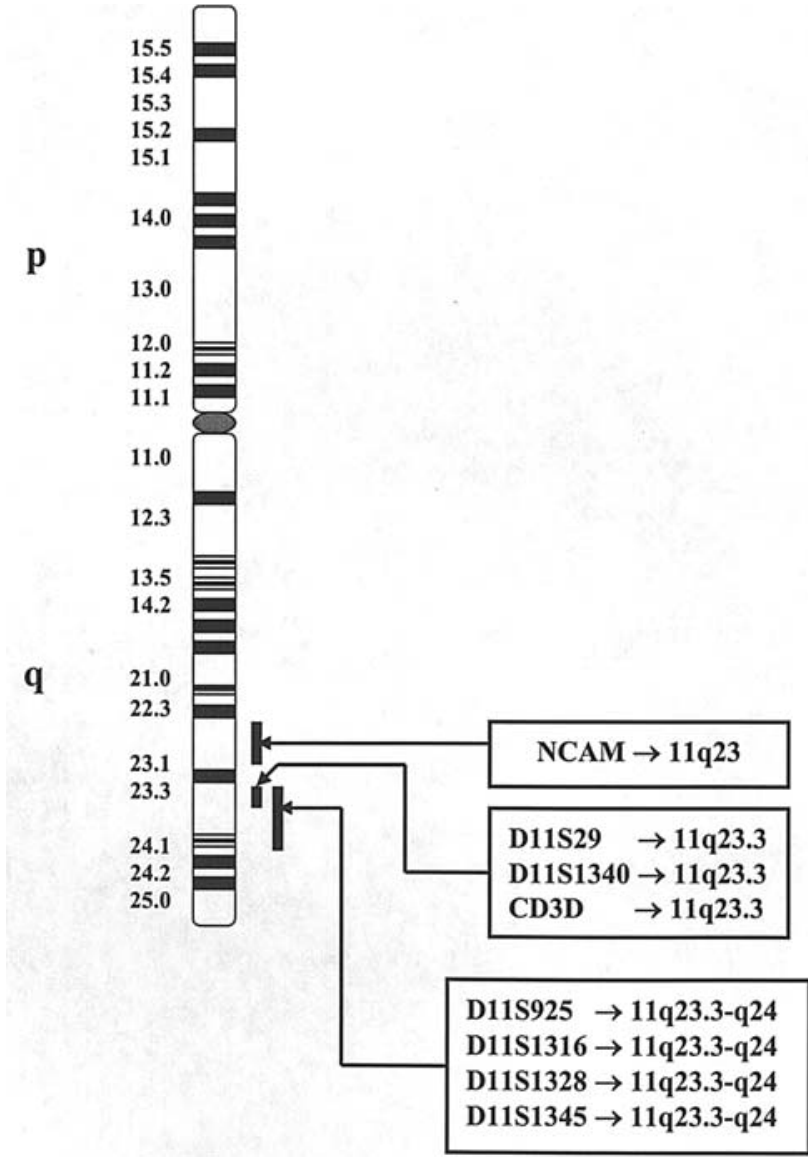

Figure 1. Map of chromosome 11 showing the putative positions of the $(\mathrm{CA})_{\mathrm{n}}$ repeat microsatellite markers used in this study. Bold black vertical lines indicate regions of possible map positions of the markers.

or near loci associated with cell-cycle regulation, DNA replication, DNA repair or signal transduction protein genes. The sequences and characteristics of microsatellite oligonucleotide primers were obtained from the GDB database (http://www.gdb.org) (Table II). We also tested D2S123 (2p16, 0.77, dinucleotide, 197-227 bp), a CA repeat marker linked to the HMSH2 gene, mapped at 2 p16, where LOH is rarely encountered (data not shown).
PCR-single strand conformation polymorphism (SSCP) analysis. PCR-SSCP was carried out in a total volume of $30 \mu 1$ containing 50-100 ng of genomic DNA, $1.5 \mathrm{mM} \mathrm{MgCl}_{2}$, $50 \mathrm{mM} \mathrm{KCl}, 10 \mathrm{mM}$ Tris- $\mathrm{HCl}(\mathrm{pH} \mathrm{8.3)}, 200 \mu \mathrm{M}$ of each dNTPs, $0.8 \mu \mathrm{M}$ of each primer (Research Genetics), and 0.75 units of AmpliTaq polymerase (Perkin-Elmer Corp., Foster City, CA) (41). One of the primers was 5'-end-labeled with $\left[\gamma^{-32} \mathrm{P}\right] \mathrm{ATP}$ at $3000 \mathrm{Ci} / \mathrm{mmol}$ (Amersham Pharmacia Biotech., IL) by $\mathrm{T}_{4}$-polynucleotide kinase (Amersham Life Science, IL). After a 5-min pre-incubation period at $94^{\circ} \mathrm{C}$, DNA was amplified for 35 cycles each comprising of $45 \mathrm{sec}$ at $94^{\circ} \mathrm{C}, 45 \mathrm{sec}$ at $55^{\circ} \mathrm{C}$, and $1 \mathrm{~min}$ at $72^{\circ} \mathrm{C}$, followed by a 7 -min final extension at $72^{\circ} \mathrm{C}$ using the GeneAmp ${ }^{\circledR}$ PCR System 2400 (Perkin-Elmer Corp.). The PCR products were processed by diluting $1: 1$ in denaturing loading buffer $(95 \%$ formamide, $20 \mathrm{mM}$ EDTA, $0.05 \%$ xylene cyanol $\mathrm{FF}$, and $0.05 \%$ bromophenol blue); denatured at $95^{\circ} \mathrm{C}$ for $5 \mathrm{~min}$ and then freezed at $4^{\circ} \mathrm{C}$. About $2 \mu \mathrm{l}$ of aliquot was loaded and electrophoresed in $6 \%$ polyacrylamide gels containing $8.3 \mathrm{M}$ urea for $2-3 \mathrm{~h}$ at $40 \mathrm{~W}$. The gel was fixed in $10 \%$ methanol$10 \%$ acetic acid, dried and exposed to Kodak X-OMAT-AR film (Eastman Kodak Co., Rochester, NY) at $-70^{\circ} \mathrm{C}$ with intensifying screen for 12-16 h as described previously (31). Every PCR reaction was repeated 2-3 times with different adjacent passages of cells to get consistent results.

Assessment of allelic losses. MSI and LOH were screened by PCR amplification of polymorphic microsatellite markers. An MSI was defined as a shift of a specific allelic band or a change (increase or decrease) in the broadness of a specific allelic band in the autoradiograms, whereas LOH was defined as a total loss (complete deletion) or a $50 \%$ or more reduction (in signal density) in one of the heterozygous alleles in autoradiograms. It was first scored by visual inspection of autoradiograms and then band intensity was quantified in a densitometric scanner (Model 300A, Molecular Dynamics) by using bioimage software Image Quant (version 3.3; Molecular Dynamics). The optical density range of 0.01-4.0 was chosen in O.D. units whereas resolution (spatial) selected at 100 points/ $\mathrm{cm}$ in both $\mathrm{X}$ and $\mathrm{Y}$ direction. The resolution (signal) was selected at 4096 levels (12-bit) of optical density. 
Table II. Sequence of sense and antisense primers of microsatellite markers.

\begin{tabular}{|c|c|c|c|}
\hline $\begin{array}{l}\text { Chromosomal } \\
\text { locus }\end{array}$ & Primer name & $\begin{array}{c}\text { Primer sequence } \\
\text { sense }\left(5^{\prime} \rightarrow 3^{\prime}\right) \text { /antisense }\left(5^{\prime} \rightarrow 3^{\prime}\right)\end{array}$ & $\begin{array}{l}\text { Important genes found } \\
\text { with these markers }\end{array}$ \\
\hline D11S29 & $7.1 / 7.2$ & $\begin{array}{l}\text { TCTAGCTCCACCATCCTGTG/ } \\
\text { ACAACACACTGCCACAAGAC }\end{array}$ & ATM and malignant melanoma \\
\hline D11S1340 & $\begin{array}{l}\text { AFM295xg5a/ } \\
\text { AFM295xg5m }\end{array}$ & $\begin{array}{l}\text { GCTGAATGAGTCCTGAGTAATAA/ } \\
\text { GGCCTAGACGTTCTTTTGTG }\end{array}$ & Breast and ovarian cancer \\
\hline CD3D & $214 / 215$ & $\begin{array}{l}\text { TAGCTGGTGCATAAGCTCAC/ } \\
\text { GTTAGTGGAAGAGCAGAGC }\end{array}$ & Tsg in breast \\
\hline NCAM & 37.F1/37.F2 & $\begin{array}{l}\text { TATCTCCCAGTTTTGCTTCT/ } \\
\text { GCTCCTTTGGTTTTATTTAG }\end{array}$ & $\begin{array}{l}\mathrm{Sfg} \text { and } \mathrm{PgR} \text { in breast, } \\
\mathrm{L} 1 \text { retro transposon }\end{array}$ \\
\hline D11S925 & $\begin{array}{l}\text { AFM220yb6a/ } \\
\text { AFM220yb6m }\end{array}$ & $\begin{array}{l}\text { AGAACCAAGGTCGTAAGTCCTG/ } \\
\text { TTAGACCATTATGGGGGCAA }\end{array}$ & Breast melanoma and lung cancer \\
\hline D11S1316 & $\begin{array}{l}\text { AFM214xg7a/ } \\
\text { AFM214xg7m }\end{array}$ & $\begin{array}{l}\text { GGGCTAGAGTCAAGGCCAA/ } \\
\text { AAAAAAGTTCCCACTCAGATGC }\end{array}$ & Tsg in breast and ZNF202 gene \\
\hline D11S1328 & $\begin{array}{l}\text { AFM265wa9a/ } \\
\text { AFM265wa9m }\end{array}$ & $\begin{array}{l}\text { TAAGTCAGGAGCAGGGTATAATGCC/ } \\
\text { GAGCCTGTCCTTGGAACACAGTAA }\end{array}$ & $\mathrm{LOH}$ in breast and lung cancer \\
\hline D11S1345 & $\begin{array}{l}\text { AFM302xb9a/ } \\
\text { AFM302xb9m }\end{array}$ & $\begin{array}{l}\text { TGCCACAGTAATACATGTGTGTAAT/ } \\
\text { TAGTCAGTGCTGAGCCCATA }\end{array}$ & Tsg in breast \\
\hline
\end{tabular}

${ }^{\mathrm{a} A T M}$, ataxia telangiectasia; Tsg, tumor suppressor gene; Sfg, suppressor factor gene; PgR, progesterone receptor.

Multiplex FISH ( $m$ FISH) analysis. MCF-10F control, irradiated $60 \mathrm{cGy} / 60 \mathrm{cGy}$, tumorigenic $60 \mathrm{cGy}+\mathrm{E} / 60 \mathrm{cGy}+\mathrm{E}$ and Tumor 2 cell lines were harvested at $40-48 \mathrm{~h}$ for metaphase preparations following a $2-\mathrm{h}$ colcemid $(0.1 \mu \mathrm{g} / \mathrm{ml}$ for $4 \mathrm{~h})$ treatment using routine procedures. After hypotonic swelling $(0.075 \mathrm{M} \mathrm{KCl})$ for $15 \mathrm{~min}$ at $37^{\circ} \mathrm{C}$, the cells were fixed in a methanol:acetic acid $(3: 1)$ mixture. The cell suspension was then dropped onto a wet, clean slide for use in FISH. For long-term storage, the fixed cells were kept at $-20^{\circ} \mathrm{C}$ until use. mFISH 24-color chromosome-specific painting probes were used in a single hybridization. The detection of at least 24 different chromosome-painting probes was performed with five varicolored fluorochromes. Each paint was labeled with one of the five fluorochromes or a unique combination (combinatorial labeling) (14). The separation of different excitation and emission spectra is guaranteed by appropriate filter sets (DAPI, DEAC, FITC, Spectrum Orange, Texas Red and Cy5) by following the manufacturer's procedure of the 24Xcyte mFISH kit (Metasystems, Germany) (42). The resulting unequivocal color signature for each chromosome enables the analysis of hidden or complex chromosomal aberrations as well as the composition of the marker chromosomes. Pretreatment consisted of RNase A $(100 \mu \mathrm{g} / \mathrm{ml})$ for $1 \mathrm{~h}$ at $37^{\circ} \mathrm{C}$ and pepsin $(50 \mu \mathrm{g} / \mathrm{ml}$ in $10 \mathrm{mM} \mathrm{HCl})$ for $2 \mathrm{~min}$ at $20^{\circ} \mathrm{C}$. For hybridization, cells were denatured in $70 \%$ formamide/2X SSC at $72^{\circ} \mathrm{C}$ for $3 \mathrm{~min}$ and dehydrated for $1 \mathrm{~min}$ each in $70 / 90 / 100 \%$ ethanol. Cells were left to hybridize for $36-48 \mathrm{~h}$ at $37^{\circ} \mathrm{C}$ before being washed in $0.4 \mathrm{X} \mathrm{SSC} / 0.1 \%$ Igepal (Sigma Chemical Co.) for $71^{\circ} \mathrm{C}$ for $1.5 \mathrm{~min}$ and then $2 \mathrm{X} \mathrm{SSC} / 0.1 \%$ Igepal at room temperature. Metaphase chromo- somes were visualized using an Axioplan II imaging microscope (Zeiss, Germany) equipped with an HBO 100 mercury lamp and filter sets for DAPI, DEAC, FITC, Spectrum Orange, Texas Red and Cy5. Images were captured and processed using the isis/mFISH imaging system (Metasystems) (43). The software controls the motorized filter revolver as well as the excitation and emission filter wheels associated with the charged-coupled device (CCD) camera thus automating the capturing process. A cell was classified as being apparently normal along their appropriate combinatorial paint composition down their entire length when all the 46 chromosomes were clearly observed by this process, and subsequently confirmed by the Axioplan II imaging microscope and the isis/mFISH imaging system. Exchange aberrations involving three or more breaks in two or more chromosomes were classed as complex and assigned the most conservative C/A/B (minimum number of chromosomes/arms/breaks involved) $(27,44)$.

\section{Results}

A total of eight microsatellite markers from chromosome 11q23-q24 were used to assess the allelic alterations in different irradiated, tumorigenic and tumor cell lines by PCR-SSCP. The different degrees of allelic imbalance were expressed in the form of MSI or LOH. These changes were found to be more pronounced in cell lines exposed to double doses of radiation and treated with estrogen and directly correlated with the phenotypic characteristics of the cell lines as it progressed from early to late stage of transformation and became tumorigenic (30). 


\begin{tabular}{|l|c|l|l|}
\hline MARKER & $\begin{array}{c}\text { MAP } \\
\text { POSITION }\end{array}$ & MCF-10F & 60cGy \\
\hline D11S29 & $11 \mathrm{q} 23.3$ & & \\
\hline D11S1340 & $11 \mathrm{q} 23.3$ & & \\
\hline CD3D & $11 \mathrm{q} 23.3$ & & \\
\hline NCAM & $11 \mathrm{q} 23$ & & \\
\hline D11S925 & $11 \mathrm{q} 23.3-\mathrm{q} 24$ & & \\
\hline D11S1316 & $11 \mathrm{q} 23.3-\mathrm{q} 24$ & & \\
\hline D11S1328 & $11 \mathrm{q} 23.3-\mathrm{q} 24$ & & \\
\hline D11S1345 & $11 \mathrm{q} 23.3-\mathrm{q} 24$ & & \\
\hline
\end{tabular}

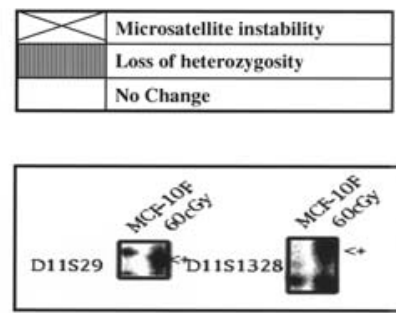

[a]

\begin{tabular}{|l|c|l|l|}
\hline MARKER & $\begin{array}{c}\text { MAP } \\
\text { POSIT1ON }\end{array}$ & MCF-10F & $\begin{array}{c}\text { 60cGy/60cGy } \\
\text { (Late) }\end{array}$ \\
\hline D11S29 & $11 \mathrm{q} 23.3$ & & \\
\hline D11S1340 & $11 \mathrm{q} 23.3$ & & \\
\hline CD3D & $11 \mathrm{q} 23.3$ & & \\
\hline NCAM & $11 \mathrm{q} 23$ & & \\
\hline D11S925 & $11 \mathrm{q} 23.3-\mathrm{q} 24$ & & \\
\hline D11S1316 & $11 \mathrm{q} 23.3-\mathrm{q} 24$ & & \\
\hline D11S1328 & $11 \mathrm{q} 23.3-\mathrm{q} 24$ & & \\
\hline D11S1345 & $11 \mathrm{q} 23.3-\mathrm{q} 24$ & & \\
\hline
\end{tabular}

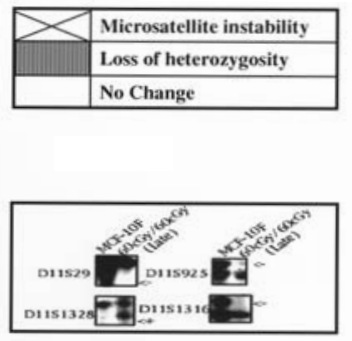

[c]

\begin{tabular}{|l|c|l|l|}
\hline MARKER & MAP & MCF-10F & Tumor 2 \\
POSITION & & \\
\hline D11S29 & $11 \mathrm{q} 23.3$ & & \\
\hline D11S1340 & $11 \mathrm{q} 23.3$ & & \\
\hline CD3D & $11 \mathrm{q} 23.3$ & & \\
\hline NCAM & $11 \mathrm{q} 23$ & & \\
\hline D11S925 & $11 \mathrm{q} 23.3-\mathrm{q} 24$ & & \\
\hline D11S1316 & $11 \mathrm{q} 23.3-\mathrm{q} 24$ & & \\
\hline D11S1328 & $11 \mathrm{q} 23.3-\mathrm{q} 24$ & & \\
\hline D11S1345 & $11 \mathrm{q} 23.3-\mathrm{q} 24$ & \\
\hline
\end{tabular}

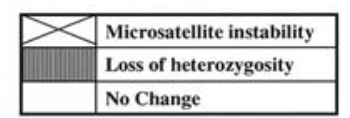

[e]

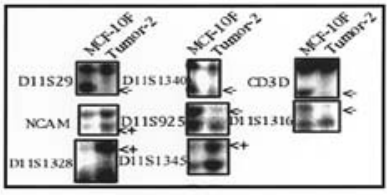

\begin{tabular}{|l|c|l|l|}
\hline MARKER & $\begin{array}{c}\text { MAP } \\
\text { POSITION }\end{array}$ & MCF-10F & $\begin{array}{c}\text { 60cGy/60cGy } \\
\text { (Early) }\end{array}$ \\
\hline D11S29 & $11 \mathrm{q} 23.3$ & & \\
\hline DIIS1340 & $11 \mathrm{q} 23.3$ & & \\
\hline CD3D & $11 \mathrm{q} 23.3$ & & \\
\hline NCAM & $11 \mathrm{q} 23$ & & \\
\hline D11S925 & $11 \mathrm{q} 23.3-\mathrm{q} 24$ & & \\
\hline D11S1316 & $11 \mathrm{q} 23.3-\mathrm{q} 24$ & & \\
\hline D11S1328 & $11 \mathrm{q} 23.3-q 24$ & & \\
\hline D11S1345 & $11 \mathrm{q} 23.3-q 24$ & & \\
\hline
\end{tabular}

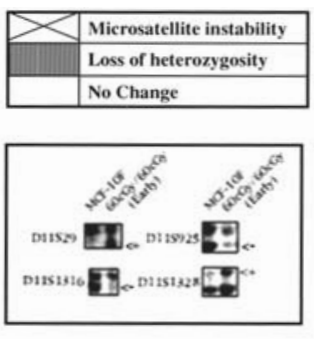

[b]

\begin{tabular}{|l|c|c|c|}
\hline MARKER & MAP & MCF-10F + E & $\begin{array}{c}\text { 60cGy+E/ } \\
\mathbf{6 0 c G y + E}\end{array}$ \\
\hline D11S29 & $11 \mathrm{q} 23.3$ & & \\
\hline D11S1340 & $11 \mathrm{q} 23.3$ & & \\
\hline CD3D & $11 \mathrm{q} 23.3$ & & \\
\hline NCAM & $11 \mathrm{q} 23$ & & \\
\hline D11S925 & $11 \mathrm{q} 23.3-\mathrm{q} 24$ & & \\
\hline D11S1316 & $11 \mathrm{q} 23.4-\mathrm{q} 24$ & & \\
\hline D11S1328 & $11 \mathrm{q} 23.4-\mathrm{q} 24$ & & \\
\hline D11S1345 & $11 \mathrm{q} 23.3-\mathrm{q} 24$ & & \\
\hline
\end{tabular}
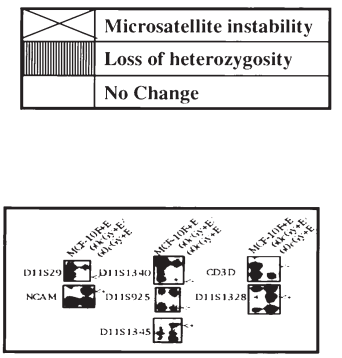

[d]

\begin{tabular}{|l|c|l|l|}
\hline MARKER & MAP & $\begin{array}{l}\text { MCF- } \\
\text { 10F }\end{array}$ & MCF-7 \\
\hline P11S29 & $11 \mathrm{q} 23.3$ & & \\
\hline D11S1340 & $11 \mathrm{q} 23.3$ & & \\
\hline CD3D & $11 \mathrm{q} 23.3$ & & \\
\hline NCAM & $11 \mathrm{q} 23$ & & \\
\hline D11S925 & $11 \mathrm{q} 23.3-\mathrm{q} 24$ & & \\
\hline D11S1316 & $11 \mathrm{q} 23.3-\mathrm{q} 24$ & & \\
\hline D11S1328 & $11 \mathrm{q} 23.3-\mathrm{q} 24$ & & \\
\hline D11S1345 & $11 \mathrm{q} 23.3-\mathrm{q} 24$ & & \\
\hline
\end{tabular}

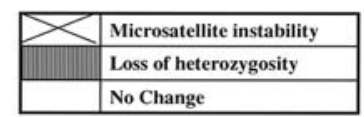

[f]

Figure 2. Frequency of MSI and LOH screened at the respective loci of $(\mathrm{CA})_{\mathrm{n}}$ repeat markers of chromosome 11 in tumor cell lines. Alterations are indicated by the following signs: $<-$, loss of heterozygosity $(\mathrm{LOH}) ;<+$, microsatellite instability (MI).

The MCF-10F cell line from a single $60 \mathrm{cGy}$ dose of exposure was compared to control MCF-10F and a total of two loci were altered in the form of MSI at loci 11q23.3 (11S29) and 11q23.3-q24 (D11S1328), and no LOH was detected (Fig. 2a). When the cell lines were exposed to $60 \mathrm{cGy} / 60 \mathrm{cGy}$ double doses of irradiation and compared at early stage with the parental MCF-10F cell lines, a total of four alterations were detected (Fig. 2b). Two of them were due to MSI at loci 11q23.3 (D11S29), 11q23.3-q24 (D11S1328). The remaining two alterations were due to LOH at loci 11q23.3-q24 (D11S925 and D11S1316). However, when late stage passage of this cell line ( $60 \mathrm{cGy} / 60 \mathrm{cGy})$ was compared with similarly passage control cells, four alterations were also identified, but in this case, three alterations were due to $\mathrm{LOH}$ and one due to MSI (Fig. 2c). Among these three LOHs, two were similar to the earlier stage (D11S925 and D11S1316) and the other one was at locus 11q23.3 (11S29). MSI was observed at 11q23.3-q24 (D11S1328) as in the early passage cultures. Similarly, by comparing the tumorigenic $60 \mathrm{cGy}+\mathrm{E} / 60 \mathrm{cGy}+\mathrm{E}$ cell line with the non-transformed MCF-10F + E (Fig. 2d), a total of seven alterations were identified, four for $\mathrm{LOH}$ and the remaining three for MSI. Loss of heterozygosity was detected at loci 11q23.3 (D11S29, D11S1340 and CD3D) and 11q23.3q24 (D11S925) whereas microsatellite instability was identified at loci 11q23 (NCAM) and 11q23.3-q24 (D11S1328 and D11S1345). A total of eight alterations were screened for MSI and $\mathrm{LOH}$ in the Tumor 2 cell line (Fig. 2e) and among them three were classified as MSI and remaining five as $\mathrm{LOH}$. These three MSIs were similar to the tumorigenic $60 \mathrm{cGy}+\mathrm{E} /$ $60 \mathrm{cGy}+\mathrm{E}$ cell line and among the five LOHs, four were 


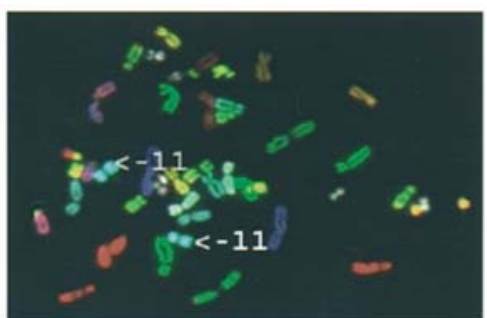

MCF - 10F

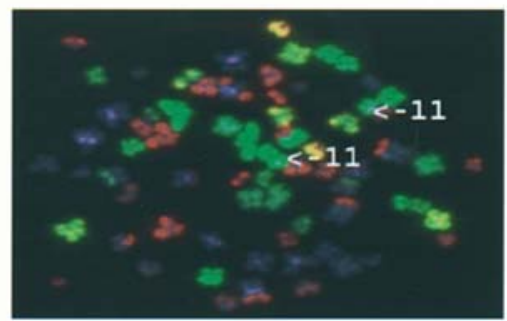

$\mathrm{MCF}-10 \mathrm{~F}+(60 \mathrm{cGY}+\mathrm{E}) /(60 \mathrm{CGY}+\mathrm{E})$

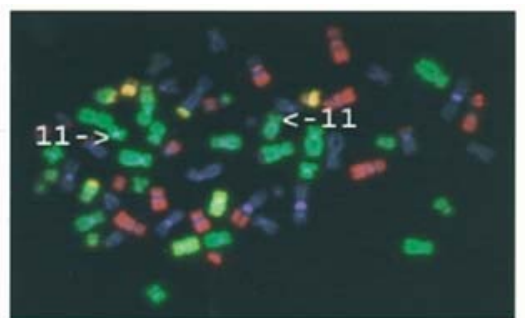

MCF-10F + 60cGy/60cGy

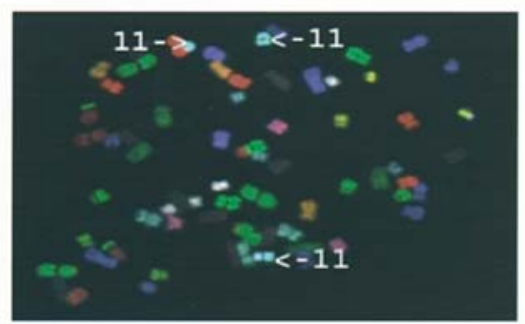

Tumor 2

Figure 3. Cell lines analysis by multiplex fluorescence in situ hybridization (mFISH). The arrowheads indicate the translocation of chromosome.

similar to the tumorigenic $60 \mathrm{cGy}+\mathrm{E} / 60 \mathrm{cGy}+\mathrm{E}$ cell line but a new alteration was detected at 11q23.3-q24 (D11S1316). The MCF-7, the positive control tumor cell line, was also compared with MCF-10F cell line and five alterations were identified. Among them, three LOHs were screened at loci 11q23.3 (CD3D), 11q23 (NCAM) and 11q23.3-q24 (D11S1328) and two MSIs at loci 11q23.3 (D11S29) and 11q23.3-q24 (D11S1345) were detected (Fig. 2f).

By using the multi-color mBAND FISH, various interand intra-arm chromosomal exchanges (damage and repair) were detected. Metaphase spread from control, irradiated, tumorigenic and tumor cell lines were used in a true or merged color profile by utilizing different fluorochromes (Fig. 3). Chromosomes are known to occupy discrete territories or domains during interphase, and it is expected that there is limited intermingling of chromatin strands. These results from intra- and inter-chromosomal association suggested that $\alpha$-particle and estrogens induced multiple damage that could induce various intermingling of chromatin strands and could assemble the damaged chromatin strands. The damage of homologous chromosome pairs can also limit their discrimination into separate independent complex events. Complex chromosomal exchanges indicating the translocation of chromosome 11 were detected in irradiated (60 cGy/60 cGy), the tumorigenic $(60 \mathrm{cGy}+\mathrm{E}) / 60 \mathrm{cGy}+\mathrm{E})$ and the tumor (Tumor 2) cell lines compared to control MCF-10F cell line (indicated by arrow sign) (Fig. 3).

\section{Discussion}

The progression of breast cancer is a very complex and diverse process involving a broad spectrum of clinical and pathological characteristics reflecting the multiplicity and heterogeneity of the disease. An array of genetic anomalies during tumor progression increases the probability of random rearrangements, which not only favor chromosomal disintegration that leads to $\mathrm{LOH}$, also favors mitotic recombination, which leads to MSI. In the present study various microsatellite polymorphic markers on loci 11q23-q24 were used to assess $\mathrm{LOH} / \mathrm{MSI}$ in the parental MCF-10F cell line and cell lines in various stages of the neoplastic transformation process. The results showed that allelic alterations were more pronounced when MCF-10F cell lines were exposed to double doses of radiation and treated with estrogen in comparison to cell lines that were treated with a single dose of radiation without estrogen. Cell lines exposed to double doses of radiation without estrogen and analyzed at different passages also showed progressive changes. During the process of cellular transformation several phenotypic changes were observed, such as anchorage-independence and invasive capabilities, under the influence of radiation, either in the presence or absence of estrogen $(30,32)$. The present report showed allele loss at 11q23-q24 loci in human breast epithelial cells induced by radiation and estrogen exposure. These alterations were probably not only due to an intrinsic level of genomic instability in these cell lines but also to cell division, thereby increasing the risk of genetic errors (45).

A progressive degree of allelic imbalance (MSI and LOH) was identified at 11q23-q24 in the early transformed stage (60 cGy), in the late transformed stage $[60 \mathrm{cGy} / 60 \mathrm{cGy}$ (early and late)], in tumorigenic stage (60 cGy + E/60 cGy + E) and in tumor cell lines established from a tumor (Tumor 2) using specific microsatellite markers belonging in this region. Aberrations in these markers are frequently associated with neoplastic progression due to their location in regions at, or near loci associated with cell-cycle regulation, DNA replication, DNA repair, or signal transduction protein genes $(46,47)$.

In the present study it was observed that a distinct region on chromosome 11q23-q24 was susceptible for LOH/MSI during radiation-induced breast cancer progression. 
Within this region, loci between D11S925 and D11S29, with an estimated size of $6 \mathrm{Mb}$ and the $\mathrm{LOH}$ region 2, between D11S1345 and D11S1316 of about $1 \mathrm{Mb}$ showed maximum alterations. Studies from other laboratories have already placed various putative tumor suppressor genes in this larger overlapping area $(48,49)$, a finding that is consistent with our present observation. Also microcell-mediated chromosome transfer of an intact copy of chromosome 11 into the tumorigenic HeLa cells has provided additional support of the presence of a tumor suppressor gene in this chromosome (50).

LOH involving these regions not only coincides with regions implicated in the pathogenesis of breast cancer but with several childhood and adult cancers including acute lymphoblastic leukemia, ovarian, prostate and bladder cancers (51-54). Identification of the same region (11q23-q24 loci) of LOH by various independent laboratories supports the importance of this region in breast cancer. Although, the precise mechanism of the high rate of $\mathrm{LOH}$ in this particular region is not known, it is evident from different observations that more than one tumor suppressor gene is residing in this region $(55,56)$.

It is known that some of the $\mathrm{LOH}$ seen on chromosome 11q23-q24 regions may represent key events during cancer progression, such as those affecting ATM or some gene(s) close or distal to it, whereas others would represent secondary mutations bearing less selective advantage (57). Cytogenetic analysis and fluorescent in situ hybridization (FISH) also indicated an unbalanced translocation of chromosomes at 11q23-q24, resulting in partial monosomy due to humoral immunodeficiency or pancytopenia (58), preliminary $\mathrm{mFISH}$ analysis of different irradiated, tumorigenic and tumor cell lines also confirmed the translocation of chromosome 11 in this model. It was observed that samples treated with both radiation and estrogen have more alterations compared to samples treated with either of them. The findings on regions of chromosomal imbalance are consistent with those found in primary breast cancer, which highlights the relevance and usefulness of this model. Further refinement of this region should be conducted using more microsatellite markers and scoring of exchange aberrations involving three or more breaks in two or more chromosomes by mFISH analysis. This analysis will ultimately allow to delineate the locations of putative tumor suppressor genes. It is the first report of a detailed analysis of allelic imbalance associated with radiation-induced progression of breast carcinogenesis, which will ultimately help to understand the mechanism of progression and how estrogen directly influence such process. An estimation of the overall incidence of alterations (e.g., by SSCP and mFISH analysis) along the long arm (e.g., 11q23-q24) of chromosome 11 will allow to identify the appropriate target(s) for therapeutic intervention that contribute to the radiation-induced breast carcinogenesis.

\section{Acknowledgements}

This work was supported by National Institute of Health grants CA49062, ES05786 and Environmental Health Center grant P30 ES09089 (T.K.H.). The grant support given by UTA 471404 and FONDECYT 1040300 (G.M.C.) is appreciated. Thanks are due to Danissa Barahona for her secretarial assistance.

\section{References}

1. Vogelstein B and Kinzler KW: The multistep nature of cancer. Trends Genet 9: 138-141, 1993.

2. Friend SH, Dryja TP and Weinberg RA: Oncogenes and tumor suppressing genes. N Engl J Med 318: 618-622, 1988.

3. Sato T, Tanigami A, Yamakawa K, Akiyama F, Kasumi F, Sakamoto G and Nakamura Y: Allelotype of breast cancer: cumulative allele losses promote tumor progression in primary breast cancer. Cancer Res 50: 7184-7189, 1990.

4. Winqvist R, Hampton GM, Mannermaa A, Blanco G, Alavaikko M, Kiviniemi H, Taskinen PJ, Evans GA, Wright FA, Newsham I and Cavenee WK: Loss of heterozygosity for chromosome 11 in primary human breast tumors is associated with poor survival after metastasis. Cancer Res 55: 2660-2664, 1995.

5. Lasko D, Cavenee W and Nordenskjold M: Loss of constitutional heterozygosity in human cancer. Annu Rev Genet 25: 281-314, 1991.

6. Nowell PC: Cancer chromosomes and genes. Lab Invest 66: 407-417, 1992.

7. Miller BA, Ries LAG, Hankey BF, Kosary CL and Edwards BK: Cancer statistics review: 1973-1989. Bethesda, MD, NCI; NIH Publication no. 92-2789, 1992.

8. Berg JW and Hutter RVP: Breast cancer. Cancer 75 (Suppl 1): 257-269, 1995.

9. Nowell PC: The clonal evolution of tumor cell populations. Science 194: 23-28, 1976.

10. Cheng KC and Loeb LA: Genomic instability and tumor progression: mechanistic considerations. Adv Cancer Res 60: 121-156, 1993.

11. Devilee P, van den Broek M, Kuipers-Dijkshoorn N, Kolluri R, Khan PM, Pearson PL and Cornelisse CJ: At least four different chromosomal regions are involved in loss of heterozygosity in human breast carcinoma. Genomics 5: 554-560, 1989.

12. Andersen TI, Gaustad A, Ottestad L, Farrants GW, Nesland JM, Tveit KM and Borresen AL: Genetic alterations of the tumor suppressor gene regions $3 p, 11 p, 13 q, 17 p$, and $17 q$ in human breast carcinomas. Genes Chromosomes Cancer 4: 113-121, 1992.

13. Anderson RM, Marsden SJ, Paice SJ, Bristow AE, Kadhim MA, Griffin CS and Goodhead DT: Transmissible and nontransmissible complex chromosome aberrations characterized by three-color and mFISH define a biomarker of exposure to highLET alpha particles. Radiat Res 159: 40-48, 2003.

14. Speicher MR, Gwyn Ballard SG and Ward DC: Karyotyping human chromosomes by combinatorial multi-fluor FISH. Nat Genet 12: 368-375, 1996 .

15. Park CC, Henshall-Powell RL, Erickson AC, Talhouk R, Parvin B, Bissell MJ and Barcellos-Hoff MH: Ionizing radiation induces heritable disruption of epithelial cell interactions. Proc Natl Acad Sci USA 100: 10728-10733, 2003.

16. Grosovsky AJ: Radiation-induced mutations in unirradiated DNA. Proc Natl Acad Sci USA 96: 5346-5347, 1999.

17. Carter SL, Negrini M, Baffa R, Gillum DR, Rosenberg AL, Schwartz GF and Croce CM: Loss of heterozygosity at 11q22-q23 in breast cancer. Cancer Res 54: 6270-6274, 1994.

18. Kollias J, Man S, Marafie M, Carpenter K, Pinder S, Ellis IO, Blamey RW, Cross G and Brook JD: Loss of heterozygosity in bilateral breast cancer. Breast Cancer Res Treat 64: 241-251, 2000

19. Tomlinson IP, Nicolai H, Solomon E and Bodmer WF: The frequency and mechanism of loss of heterozygosity on chromosome 11q in breast cancer. J Pathol 180: 38-43, 1996.

20. Negrini M, Sabbioni S, Possati L, Rattan S, Corallini A, Barbanti-Brodano G and Croce CM: Suppression of tumorigenecity of breast cancer cells by microcell-mediated chromosome transfer: studies on chromosome 6 and 11. Cancer Res 54: 1331-1336, 1994.

21. Rasio D, Negrini M, Manenti G, Dragani T and Croce CM: Loss of heterozygosity at chromosome $11 \mathrm{q}$ in lung adenocarcinoma: identification of three independent regions. Cancer Res 55: 3988-3991, 1995

22. Davis M, Hitchcock A, Foulkes WD and Campbell IG: Refinement of two chromosome 11q regions of loss of heterozygosity in ovarian cancer. Cancer Res 56: 741-744, 1996.

23. Lee AS, Seo YC, Chang A, Tohari S, Eu KW, Seow-Choen F and McGee JO: Detailed deletion mapping at chromosome $11 \mathrm{q} 23$ in colorectal carcinoma. Br J Cancer 83: 750-755, 2000.

24. Calaf G and Russo J: Transformation of human breast epithelial cells by chemical carcinogens. Carcinogenesis 14: 483-492, 1993. 
25. Calaf G, Zhang PL, Alvarado ME, Estrada S and Russo J: c-Haras oncogene enhances the neoplastic transformation of human breast epithelial cells treated with chemical carcinogens. Int J Oncol 6: 5-11, 1995

26. National Research Council, Committee on the Biological Effects of Ionizing Radiation, Health Effects of Exposure to Radon (BEIR VI). National Academy Press, Washington, DC, 1998.

27. Anderson RM, Stevens DL and Goodhead DT: M-FISH analysis shows that complex chromosome aberrations induced by $\alpha$-particle tracks are cumulative products of localized rearrangements. Proc Natl Acad Sci USA 99: 12167-12172, 2002.

28. Brenner DJ, Doll R, Goodhead DT, Hall EJ, Land CE, Little JB, Lubin JH, Preston DL, Preston RJ, Puskin JS, Ron E, Sachs RK, Samet JM, Setlow RB and Zaider M: Cancer risks attributable to low doses of ionizing radiation: assessing what we really know. Proc Natl Acad Sci USA 100: 13761-13766, 2003.

29. Goodhead DT: Track structure considerations in low-dose and low-dose rate effects of ionizing-radiation. Adv Radiat Biol 16: 7-44, 1992.

30. Calaf G and Hei TK: Establishment of a radiation- and estrogeninduced breast cancer model. Carcinogenesis 21: 769-776, 2000.

31. Roy D, Calaf G and Hei TK: Frequent allelic imbalance on chromosome 6 and 17 correlate with radiation-induced neoplastic transformation of human breast epithelial cells. Carcinogenesis 22: 1685-1692, 2001.

32. Roy D, Calaf G and Hei TK: Allelic imbalance at 11p15.5-15.4 correlated with c-Ha-ras mutation during radiation-induced neoplastic transformation of human breast epithelial cells. Int J Cancer 103: 730-737, 2003.

33. Roy D, Calaf G and Hei TK: Profiling of differentially expressed genes induced by high linear energy transfer radiation in breast epithelial cells. Mol Carcinog 31: 192-203, 2001.

34. Calaf $\mathrm{G}$ and Hei TK: Oncoprotein expression in human breast epithelial cells transformed by high-LET radiation. Int J Radiat Biol 77: 31-40, 2001

35. Soule HD, Maloney TM, Wolman SR, Peterson WD, Brenz R, McGrath CM, Russo J, Pauley RJ and Brooks SC: Isolation and characterization of a spontaneously immortalized human breast epithelial cell line, MCF-10. Cancer Res 50: 6075-6086, 1990.

36. Calaf G, Russo J, Tait L, Estrada S and Alvarado ME: Morphological phenotypes in neoplastic progression of human breast epithelial cells. J Submicrosc Cytol Pathol 32: 83-96, 2000.

37. Calaf G, Russo J and Alvarado ME: Morphological phenotypes in neoplastic progression of benz(a)alpha pyrene-treated breast epithelial cells. J Submicrosc Cytol Pathol 32: 535-545, 2001.

38. Soule HD, Vazquez J, Long A, Albert S and Brennan MA: A human cell line from a pleural effusion derived from a breast carcinoma. J Natl Cancer Inst 51: 1409-1416, 1973.

39. Gross-Bellard M, Oudet P and Chambon P: Isolation of highmolecular-weight DNA from mammalian cells. Eur J Biochem 36: 32-38, 1973 .

40. Sambrook J, Fritsch EF and Maniatis T: Molecular Cloning. A Laboratory Manual. Cold Spring Harbor Laboratory Press, 1989.

41. Jaeckel S, Epplen JT, Kauth M, Miterski B, Tschentscher F and Epplen C: Polymerase chain reaction-single strand conformation polymorphism or how to detect reliably and efficiently each sequence variation in many samples and many genes. Electrophoresis 19: 3055-3061, 1998 .

42. Chudoba I, Plesch A, Lorch T, Lemke J, Claussen U and Senger G: High resolution multicolor-banding: a new technique for refined FISH analysis of human chromosomes. Cytogenet Cell Genet 84: 156-160, 1999
43. Eils R, Uhrig S, Saracoglu K, Satzler K, Bolzer A, Petersen I, Chassery JM, Ganser M and Speicher MR: An optimized fully automated system for fast and accurate identification of chromosomal rearrangements by multiplex-FISH (MFISH). Cytogenet Cell Genet 82: 160-171, 1998.

44. Savage JR and Simpson PJ: FISH 'painting' patterns resulting from complex exchanges. Mutat Res 312: 51-60, 1994.

45. Bieche I and Lidereau R: Genetic alterations in breast cancer. Genes Chromosomes Cancer 14: 227-251, 1995.

46. Parsons R, Li GM, Longley MJ, Fang WH, Papadopoulos N, Jen J, De la Chapelle A, Kinzler KW, Vogelstein B and Modrich P: Hypermutability and mismatch repair deficiency in RER+ tumor cells. Cell 75: 1227-1236, 1993.

47. Dedhar S: Cell-substrate interactions and signaling through ILK. Curr Opin Cell Biol 12: 250-256, 2000.

48. Nagahata T, Hirano A, Utada Y, Tsuchiya S, Takahashi K, Tada T, Makita M, Kasumi F, Akiyama F, Sakamoto G, Nakamura Y and Emi M: Correlation of allelic losses and clinicopathological factors in 504 primary breast cancers. Breast Cancer 9: 208-215, 2002

49. Gentile M, Ahnstrom M, Schon F and Wingren S: Candidate tumour suppressor genes at 11q23-q24 in breast cancer: evidence of alterations in PIG8, a gene involved in p53 induced apoptosis. Oncogene 20: 7753-7760, 2001 .

50. Saxon PJ, Srivatsan ES and Stanbridge EJ: Introduction of human chromosome 11 via microcell transfer controls tumorigenic expression of HeLa cells. EMBO J 5: 3461-3466, 1986.

51. Pui CH, Chessells JM, Camitta B, et al: Clinical heterogeneity in childhood acute lymphoblastic leukemia with 11 q23 rearrangements. Leukemia 17: 700-706, 2003.

52. Launonen V, Stenback F, Puistola U, Bloigu R, Huusko P, Kytola S, Kauppila A and Winqvist R: Chromosome 11q22.3-q25 $\mathrm{LOH}$ in ovarian cancer: association with a more aggressive disease course and involved subregions. Gynecol Oncol 71: 299-304, 1998.

53. Dahiya R, McCarville J, Lee C, Hu W, Kaur G, Carroll P and Deng G: Delection of chromosome 11p15, p12, q22, q23-24 loci in human prostate cancer. Int J Cancer 72: 283-288, 1997.

54. Richter J, Wagner U, Schraml P, Maurer R, Alund G, Knonagel H, Moch H, Mihatsch MJ, Gasser TC and Sauter G: Chromosomal imbalances are associated with a high risk of progression in early invasive (pT1) urinary bladder cancer. Cancer Res 59: 5687-5691, 1999.

55. Baysal BE, Willett-Brozick JE, Taschner PE, Dauwerse JG, Devilee $\mathrm{P}$ and Devlin B: A high-resolution integrated map spanning the SDHD gene at 11q23: a 1.1-Mb BAC contig, a partial transcript map and 15 new repeat polymorphisms in a tumour-suppressor region. Eur J Hum Genet 9: 121-129, 2001

56. Martin ES, Cesari R, Pentimalli F, Yoder K, Fishel R, Himelstein AL, Martin SE, Godwin AK, Negrini $M$ and Croce CM: The BCSC-1 locus at chromosome 11q23-q24 is a candidate tumor suppressor gene. Proc Natl Acad Sci USA 100: 11517-11522, 2003

57. Laake K, Odegard A, Andersen TI, Bukholm IK, Karesen R, Nesland JM, Ottestad L, Shiloh Y and Borresen-Dale AL: Loss of heterozygosity at 11q23.1 in breast carcinomas: indication for involvement of a gene distal and close to ATM. Genes Chromosomes Cancer 18: 175-180, 1997.

58. Ounap K, Bartsch O, Uibo O and Laidre P: Girl with combined immunodeficiency, pancytopenia, malformations, deletion $11 \mathrm{q} 23.3 \rightarrow$ qter, and trisomy $8 \mathrm{q} 24.3 \rightarrow$ qter. Am J Med Genet 108: 322-326, 2002. 